\title{
Bioethics - A component of culture: development tendencies and basic features
}

\author{
Mamajonova Gulnoza Karimovna ${ }^{1}$ \\ ${ }^{1}$ Teacher of Namangan Engineering and Construction Institute, Researcher at the National \\ University of Uzbekistan, Namangan city, Uzbekistan
}

Email: mamajonova_g@umail.uz

\begin{abstract}
This article discusses the role of bioethics in the cultural system. The development of modern bioethics as a science and the stages of its formation have been analyzed.

Keywords: Bioethics, Biomedicine, Biotechnology, Ethics, Healthy Lifestyle, Human Rights
\end{abstract}

\section{INTRODUCTION}

The 21st century has entered human life with new ideas and innovative technologies. These ideas and technologies, along with serving mankind's future, prosperity, and health, have created a number of previously unknown issues.

Over the past centuries, the ethical issues in medicine have been the relationship between physicians and patients. Should a physician inform the patient and his or her family about the condition of the patient, his or her behavior, or may the patient conceal the diagnosis? And other similar issues have been the focus of medical ethics.

Rapid advances in biomedical technology have led to changes in ethics. The relationship between physician and patient related to human life and health is beyond the scope of deontology. As a result, a new science, Bioethics, that ethically analyzes the successes of genetics, genomics, and biotechnologies has emerged.

Bioethics has emerged as a unifying factor in medical science and ethics. Bioethics can be given the status of interdisciplinary science (multidisciplinary). Because it addresses and discusses medical, ethical, philosophical, legal, and religious issues.

\section{THEORETICAL BACKGROUND}

The emergence and development of bioethics as a science began in the United States. Van Rensseler introduced the term Potter Bioethics as a scientific term, with E. in its formation as an independent scientific direction and science. Pellegrino services are invaluable. At the initiative of Edmund Pellegrino, the Center for Bioethics Research was established in 1969 - the Institute for Science, Society, Ethics and Life (Gastingsky Center, New York). In 1971, the Institute of Ethics was established at Georgetown University, USA. Since then, many articles on bioethics have been published in various magazines. This has attracted many researchers and scholars to this point.

From 1974 to 1978 the Committee for the Protection of Human Rights in Biomedical Research was established. This Committee has been working to promote human rights in contemporary medical research. Since 1976, the Journal of Medicine and Philosophy has been published. The 1978 four-volume Encyclopedia of Bioethics was published. As a result of these activities, international and national Bioethics Committees began to form. These efforts have given priority to the development of Bioethics.

\section{MAIN PART}

Bioethics as a subject has been taught in many universities. In recent years, all medical colleges and universities in the United States, Europe and the East have been taught as interdisciplinary disciplines.

For example, since 2000, Bioethics has been incorporated into the Russian State Educational Standards. Many universities in Russia have Bioethics chairs. For example, the Department of Bioethics was first established at Kazan State Medical University. 
Over the past 40 years, many scientific publications on bioethics have been published. Many international conferences on bioethics have been organized.

Today, too, much attention is paid to the problems of bioethics in Uzbekistan. Numerous articles have been published on various issues and issues of bioethics. Bioethics is taught as a science in Higher Education Institutions of Medicine in Uzbekistan. The Ethics section of Philosophy in Higher Education addresses the problems of bioethics. The sample program on philosophy includes bioethics problems such as cloning, euthanasia, abortion, organ transplantation, and gene engineering.

Today, bioethics has a strong influence on the scientific, spiritual and cultural environment. The extent to which bioethics is formed remains one of the main features of cultural development. There are scientific, social and axiological foundations in the development of bioethics. These foundations have played an important role in the emergence and development of Bioethics.

\section{DISCUSSION}

The scientific basis of bioethics is related to the development of new modern biotechnologies. Transplantation, resuscitation, artificial insemination, and gene engineering are the modern directions of medical practice in any country. Bioethics is a part of biomedical medicine but at the same time has a general and universal nature. The universality of scientific knowledge means that these knowledge are not linked only by the peculiarities of any nation, ethnic group or region, but have something in common with all. The common denominator is that it differs from country to country, with varying degrees of development.

E. According to Pellegrino, "bioethics has no national or cultural boundaries." Its first basis is the universality and universality of biomedical knowledge.

The second factor of the emergence of bioethics is social need. This need arose to protect the health and rights of people from advances in science and technology. Humanitarian control of scientific research and experience in the modern system of culture remains one of the main problems of today. These problems further increase the social responsibility of researchers.

The role of "pluralism" in the development and development of bioethics is important. Recognizing and acknowledging different forms of worldview in contemporary cultural systems are seen as key features of democracy. Some of the literature is divided into liberal and conservative worldviews on Bioethics traditions and values. Different approaches to the problems of bioethics are evident in the issues of death and life.

We can classify the results of bioethics practice in the following areas:

First of all, Bioethics is the field that investigates the ethical responsibility of biomedical research results and achievements. It involves doctors, biologists, philosophers, religious scholars, psychologists, lawyers and politicians.

Second, the field of academic research. It is taught as a science in medical universities and in faculties specializing in biology, philosophy and religion.

Third, it is a rapidly evolving social sector. Today there are national, regional and international committees on Bioethics.

As a type of scientific activity, Bioethics deals with the analysis of human behavior in the field of biology and medicine with ethical values. Based on this, the main issues of Bioethics are as follows:

Protect human rights and interests in biomedical research, and build harmony in protection against their adverse effects;

The Ethical Problems of Modern Medicine;

1. Physician-patient ethics;

2. Ethical treatment of life and death;

3. Man's moral attitude towards all living things, etc.

From the foregoing, it can be argued that the main purpose of bioethics is to find moral and legal solutions to the unconventional medical and biological problems that occur during a person's lifetime and end. The main task of bioethics is to develop and implement a theory of social and legal protection of the individual.

Depending on the content, purpose and function of bioethics, it can be said that it is a broad field that covers the problems of medical deontology, medicine, ethics, law, philosophy and religion. 
The main problems of bioethics:

- Protecting patients' rights (including those with serious communicable diseases, mentally ill, children and other diseases);

- Equality in health care;

- Interaction with nature (ecological aspects of biomedical technology development);

- Abortion, contraception and new reproductive technologies (artificial insemination, surrogate motherhood);

- Conduct experiments on humans and animals;

- Development of criteria for the diagnosis of death (understanding of life and death);

- Transplantology;

- Modern genetics (genodiagnostics, gene therapy and engineering);

- manipulation of stem cells;

- Cloning (therapeutic and reproductive);

- Assisting with deadly patients (hospital and palliative care organizations);

- Suicide and euthanasia (passive or active, voluntary or compulsory).

All of these problems affect the interests of everyone and therefore require a new philosophical, legal and medical approach to these issues.

Some issues in the field of bioethics may seem small, but they are crucial to human life. After all, from the moment of birth to the last breath of life, human life is the focus of medicine.

\section{REFERENCES}

1. Van Rensselaer Potter. Bioethics: Bridge to the Future . 1971 Prentice-Hall, 205p;

2. Potter V.R. Bioethics: a bridge to the future.-K., 2002.- 216 p.

3. Bioethik in den USA, s.16.

4. Mukhamedova Zamira BIOETHICS IN UZBEKISTAN: HISTORY, ISSUES, PROSPECTSPhilosophy and life / ${ }^{1} 1 / 2$ (1) 2018

5. Mamajonova GK Bioethics - Institutional Mechanism of Social Control of Criteria for Ethical Choice and Ethical Responsibility // Journal of Sources of Science No. 5/2019 pp. 30-33

6. Nurmatova M. A., Zhabborova Yu. D., Umarova N. Kh., Khudaiberdiev A. K. Some features of the spiritual and moral education of students of medical universities // Young scientist. - 2014. - No. 6. - S. 868-870. - URL https://moluch.ru/archive/65/10682/ 